\title{
China's Eagerness to Export Its High- speed Rail Expertise to ASEAN Members
}

\author{
HONG YU
}

\begin{abstract}
The Chinese government is adopting a 'going-out' strategy to promote China's high-end rail technology overseas and strengthen its global competitiveness. This article examines China's high-speed rail diplomacy towards the Association of Southeast Asian Nations (ASEAN) and uncovers the link between China's ambitious foreign policies towards the ASEAN and both national pride and commercial stakes in promoting high-speed rail in the region. It analyses the rationale behind China's high-speed rail development proposals for the ASEAN in the context of the rise of China and rivalry between China and Japan. China is especially eager to participate in the construction of high-speed railroads with ASEAN members. The high-speed rail link can forge regional economic integration within the ASEAN. For ASEAN member states, China is a key external investor and contractor for their infrastructure development. Nevertheless, China is facing serious challenges to the realization of its proposals.
\end{abstract}

Keywords: China, ASEAN, high-speed rail, infrastructure development, ASEAN connectivity, outward investment

\section{Introduction}

The rapid economic rise of China has allowed it to increase its influence in the development of Asia and become one of the most important actors in Southeast Asia, economically, politically and strategically. Bilateral trade between China and the Association of Southeast Asian Nations (ASEAN) has grown over the last 20 years, from US\$7 billion in 1990 to US $\$ 400$ billion in 2012, a 57-fold increase. Malaysia, Indonesia, Singapore and Thailand are China's four major trading partners (Asian Development Bank 2012). Bilateral trade between China and the ASEAN has increased sharply since China became a member of the World Trade Organization in 2001. It is argued that the ASEAN-China Free Trade Area (ACFTA) will further strengthen bilateral trade cooperation and increase the volume of bilateral trade (Devadason 2010). The three principal channels for market-driven integration of the Chinese economy with 
other Asian economies are viewed as trade, foreign direct investment and a complementary regional production network with China as the assembly centre and export platform for final goods (Das 2013). China has proposed upgrading the ACFTA and aims to achieve bilateral trade worth up to US $\$ 1$ trillion by 2020 . At the same time, China has engaged in a rapidly increasing number of large-scale, contracted projects for transport and other crucial infrastructure development in the ASEAN region, including construction of roads, expressways, bridges, dams, port facilities and power plants.

Previous studies on China-ASEAN relations have focused heavily on bilateral trade, ACFTA and territorial and maritime disputes in the South China Sea (SCS) between China and some ASEAN member states. However, the rationale behind China's high-speed rail diplomacy and charm offensive aimed at ASEAN members and the challenges facing China in achieving its ASEAN goals have rarely been examined. In addition, although ASEAN has become the major site for the high-speed rail contest between Japan and China, there is a lack of academic scrutiny of this rivalry. What is the motivation and rationale for China's highspeed rail diplomacy towards the ASEAN? What strategy has China adopted to access markets for high-speed rail and other infrastructure development in Southeast Asia? Who are the major opponents to China's plan to develop high-speed rail in the region? What are the major challenges for China's high-speed development proposals? This article intends to bridge this research gap by examining these issues in relation to the thinking behind China's eagerness to export its high-speed rail technology to ASEAN members, and the challenges facing implementation of its proposals.

China has made astonishing strides in the development of high-speed railway (known as the gaotie 中国高铁 in Chinese) over the past few years. Prior to 2003, China still did not have a single kilometre of highspeed railway; now it has the world's largest high-speed rail network, with nearly 10,000 kilometres of track in operation by 2012 (Figure 1). Almost all of the provincial-level regions in China are connected by the high-speed rail transport network. China now leads the world in highspeed rail development and its high-speed rail technology has become a global promotion brand, with great appeal for many countries. The fast expansion of China's high-speed railroads is attracting worldwide attention, with The Economist, World Bank, BBC, New York Times and Wall Street Journal among others having recently provided in-depth coverage of this significant development and its domestic implications. ${ }^{1}$ 
FIGURE 1: The Operational Length of High-speed Rail and Railway Networks in China

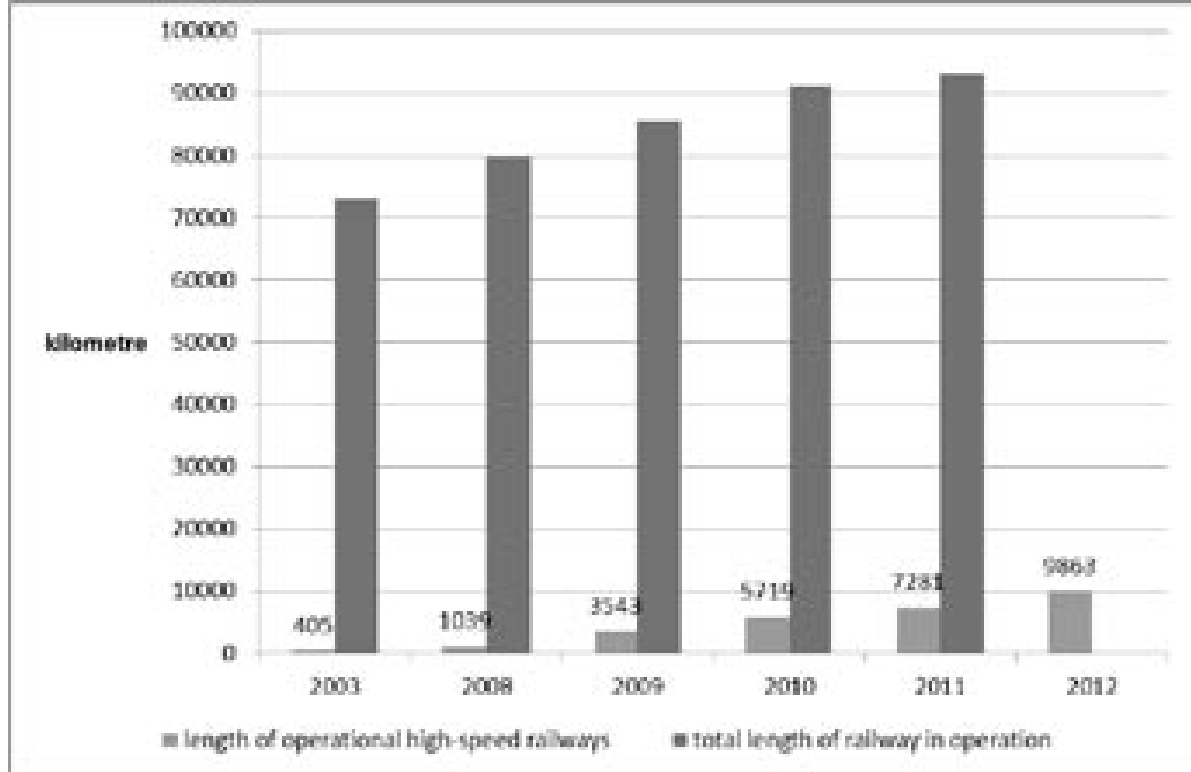

Note: The data refers to high-speed rail networks capable of running at speeds over 200 kilometres per hour.

Source: China Statistical Yearbook 2012; the data on the high-speed railway was compiled by the author based on updated information.

With the rapid development of China's high-speed railway, it is timely to analyse China's eagerness to export its high-speed rail technology to the ASEAN. China's high-speed rail development proposals to the ASEAN are a reflection of China's economic ascendance as well as its growing power in the global arena. China's high-speed rail diplomacy to the ASEAN is viewed as a grand vision of interregional rail network connectivity between China and its neighbours in Asia (Reilly 2012). Promoting China's high-speed rail in the ASEAN region reflects the Chinese government's efforts to project China's economic might, increase its economic and diplomatic influence, and assert its political, strategic and economic interests in the ASEAN region.

Economic prosperity is based on infrastructure development. A comprehensive and efficient infrastructure system is crucial to unlocking geographical constraints and achieving rapid national economic growth. Economic geography theorists have long argued the importance of infrastructure development in overcoming backward geographic conditions and reducing the high costs of production in landlocked countries (Kraft, Meyer and Valette 1971; Skinner 1994; Radelet and Sachs 1998; Bougheas, Demetriades and Morgenroth 
1999; Henderson, Salizi and Venables 2001). Infrastructure acts as a critical force to boost regional development and thereby provides the foundation for industrial and economic prosperity ( $\mathrm{Yu}$ 2011). Infrastructure improvement can unleash development advantages of landlocked regions such as low labour and land costs. Modern infrastructure facilities are viewed as one of the most important factors in stimulating regional economic development. Conversely, the lack of such infrastructure can seriously deter private investors from investing in landlocked regions and consequently impede these regions' economic growth. The experience of economic growth in the developed European countries, Asian countries and North America illustrates the importance of transport and other critical infrastructure development in shaping regional economic take-off and prosperity. For instance, Sapir's study (1990) of South Korea describes how public investment in infrastructure construction helped transform it from an economically poor to a developed nation.

Infrastructure improvement is the foundation for economic development. Nevertheless, infrastructure, although necessary, is not the only requirement for pursuing economic development. Capable and efficient institutions, educational development, availability of a skilled labour force, domestic savings, and provision of a pro-business investment environment are all necessary pre-conditions to achieving economic growth. The development experiences of the East Asian miracle in countries such as South Korea and Singapore are cases in point.

The structure of this article is as follows: the next section discusses China's high-speed rail diplomacy to the ASEAN. Section three examines the role of infrastructure development in ASEAN connectivity and the status of infrastructure in the ASEAN. Section four considers China's infrastructure development plan for the ASEAN and its rationale and motivation. Section five discusses the ongoing rivalry and competition between Japan and China in the promotion of high-speed rail in the region, and illustrates how China could best overcome this opposition. Section six provides analysis on the challenges facing implementation of China's proposals, with focus on the territorial conflicts and disputes in the SCS. The final section draws conclusions.

\section{China's High-speed Rail Diplomacy in the ASEAN}

There is a well-known saying that China has to produce and export millions of shirts in order to buy a Boeing or Airbus aircraft built in 
the United States or Europe. This is a reflection of China's status as a labour-intensive and low-end manufacturing base. However, after 30 years of huge investment in research and development activities, adopting learning from Western advanced technology, and developing home-grown innovation, China is apparently ready to export its domestically made, high-tech industrial products overseas. A trend of China exporting a wide range of high-end and high-tech industrial goods is taking shape. For example, China will collaborate with the French power giant EDF to build a new generation nuclear power plant in Hinkley Point in Somerset, Great Britain, in a deal announced by the British chancellor George Osborne during his visit to China in October 2013. ${ }^{2}$ This planned new nuclear power plant will incorporate Chinese technology and Chinese-manufactured components.

The case of high-speed rail expertise offers a glimpse of the dramatic progress China has made in developing high-value-added and high-tech products based on the most advanced technology. The Chinese government supports the Chinese high-speed rail manufacturing industry's entry into foreign markets and is promoting its high-speed rail technology globally in Asia, Europe and the Americas, and therefore a form of 'high-speed rail diplomacy' has emerged. China has already signed a memorandum of understanding on railway sector cooperation with Russia, Brazil and Turkey; and in 2012, the Chinese railway companies won construction contracts for high-speed railway and trains in Turkey and Iran. ${ }^{3}$

The new Chinese government intends to make the railway sector a top priority in expanding China-ASEAN cooperation, and is more willing than its predecessors to seek business opportunities abroad for China's high-speed rail technology. Hence, China is launching a charm offensive to show off its expertise in high-speed rail technology to the ASEAN. Due to its financial resources, technological capability and abundance of skilled labour, China is ideally placed to take on high-speed railroad projects in foreign markets.

At China's invitation, trade ministers from the ten ASEAN member states travelled to Beijing by high-speed train in October 2013. This move was intended to gain ASEAN endorsement for China's high-speed rail technology and increase confidence in its safety. The planned construction of the Bangkok-Chiang Mai and the Kuala Lumpur-Singapore high-speed rail lines are critical infrastructure projects for the ASEAN in terms of both national and interregional connectivity. According to a World Bank study, the high-speed railroad can generate substantial eco- 
nomic agglomeration effects to the connected regions and thus stimulate their economic growth. ${ }^{4}$ China is keen to take part in the construction of these two high-speed railroads.

\section{The Kuala Lumpur-Singapore High-speed Railway}

During their bilateral meeting in February 2013, Najib Razak, the prime minister of Malaysia, and Lee Hsien Loong, prime minister of Singapore, jointly announced a project to build a high-speed rail line (to run at $300 \mathrm{~km} /$ hour or above) between Kuala Lumpur (KL) and Singapore by 2020 . The KL-Singapore high-speed railway was proposed in the late 1990s. The construction cost is estimated at around US $\$ 13$ billion. The KL-Singapore high-speed railway is intended to alleviate the serious intercity road congestion and to meet increasing transport demand between these two countries. Once completed, it is expected that this high-speed railway will cut the travel time between KL and Singapore to one and a half hours. According to the study by the Land Public Transport Commission of the Government of Malaysia, the KL-Singapore high-speed railway will also help to generate spillover economic effects to the surrounding cities along this rail line and forge closer economic cooperation between Singapore and Malaysia by encouraging development in the six local industrial clusters along the train route, namely Kuala Lumpur, Seremban, Melaka, Muar, Batu Pahat and Johor, Malaysia. ${ }^{5}$ China had been eyeing this 330 kilometrelong high-speed rail project.

\section{The Bangkok-Chiang Mai High-speed Rail Line}

China has shown strong interest in being involved in the development of a high-speed rail line to connect Bangkok with Chiang Mai, Thailand. The proposed line will cut the travel time between these two cities to about three hours from the current 11-hour journey. Over the years, China and Thailand have developed a close strategic relationship that encompasses the political, economic, cultural, education and defence sectors, and is referred to by both the Chinese and Thai governments as the 'one family relationship'. 6

The Thai government is focusing on the development of mega-infrastructure construction as the main strategy for overcoming the transport gridlock and accelerating the economic growth of Thailand up to 2020. The Thai government plans to spend US $\$ 60$ billion on projects such as high-speed rail to modernize its ageing transportation facilities and increase the connectivity and accessibility of its cities. ${ }^{7}$ 
During Chinese Premier Li Keqiang's visit to Thailand in October 2013, Premier Li and his Thai counterpart Yingluck Shinawatra jointly attended the opening ceremony of an exhibition on China's high-speed railways. Li played the role of super salesperson in promoting China's high-speed rail technology to Yingluck and the Thai public during this occasion. The Chinese and Thai governments signed an agreement in principle on railway sector cooperation in October 2013. China has already completed the field geological surveys along this proposed high-speed rail route, which has made the state-owned China Railway Corporation, the world's largest railway company, the front-runner to bid for the Bangkok-Chiang Mai high-speed rail project. The estimated construction cost of this fast rail line is about US $\$ 12.8$ billion. ${ }^{8}$

\section{Role and Status of Infrastructure Development in ASEAN Connectivity}

In pursuing economic take-off, many ASEAN countries have faced the common challenge of backward and shoddy infrastructure. The standard of their infrastructure in terms of the 2013 global competitive index on infrastructure development is provided in Table 1. To unlock their development potential, these countries have to undertake the urgent task of accelerating infrastructure development and improve interregional infrastructure connectivity. This process offers a huge market for those Chinese companies that have the advanced technology and experience to carry out international infrastructure construction projects. Hence, China is eager to gain wide access to the ASEAN's infrastructure market.

A well-developed transportation network can help to forge an integrated national market, and is key to developing an interregional economic community across the ASEAN. The availability of a well-connected interregional infrastructure network is a critical pre-condition to full realization of the physical element of the ASEAN's Connectivity Master Plan $^{9}$ and achieving the goal of the ASEAN community by 2015. It is important for boosting intraregional and interregional trade, and economic as well as cultural linkages. In particular, the ASEAN Master Plan has identified the development of interregional railroads (the so-called Singapore Kunming Rail Link, SKRL) as one of the priority projects. The various SKRL routes will pass through Singapore, Malaysia, Thailand, Myanmar, Cambodia, Laos, Vietnam and Kunming, China. 
High-speed rail has been used mainly to serve the passenger traffic network, rather than goods transportation. Compared to other transport modes such as conventional railway, road and maritime shipping, the relatively high cost of using high-speed railway makes it less competitive for cargo goods transport. The importance of high-speed rail is to facilitate communication among people and reduce their travel time.

Taking this into account, the increase in trade and subsequent construction of transportation infrastructure is not linked directly to the development of the high-speed rail network, but to other types of transportation. The high-speed railway is symbolic in that it has played a very limited role in promoting trade and facilitating the flow of goods. Nevertheless, high-speed rail still has a role to play and is an important step in developing a comprehensive and integrated transport network connecting China and the ASEAN countries.

The infrastructure development gap among ASEAN members is striking. While a few countries, such as Singapore, have developed state-ofthe-art, modern infrastructure, other relatively underdeveloped member states, such as the Philippines, Myanmar, Laos and Cambodia, use outdated and inefficient transportation and other infrastructure facilities. They are unable to meet the infrastructure demands of their increasing middle-class populations and the rapid urbanization within the region. By 2020, Thailand, Malaysia, Philippines and Indonesia will between them have 40 million new urban residents. ${ }^{10}$ The ASEAN countries are faced with the challenging task of upgrading road, air transport, port and railroad infrastructure that is totally inadequate. According to the global competitiveness index published by the World Economic Forum in 2013, Singapore was one of the world's leaders in infrastructure development. Malaysia also performed consistently well in terms of various indicators of infrastructure quality, although there is some room for improvement. Nevertheless, the majority of ASEAN member nations come out very poorly in international comparisons of quality of infrastructure. This is especially true of Indonesia, the Philippines, Vietnam, Cambodia and Myanmar, with Myanmar being one of the lowest-ranked countries in the world for most of the infrastructure quality indicators (Table 1).

As their existing infrastructure was built a long time ago, many ASEAN member states urgently need to upgrade their existing transportation facilities and construct new infrastructure projects in order to boost economic growth and realize their development potential. A case in point is Thailand, where there is growing concern among the domestic and foreign business communities over the adverse effect 
TABLE 1: Infrastructure Performance of ASEAN Members in the 2013-2014 Global Competitiveness Index (based on ranking of 148 countries/economies)

\begin{tabular}{|l|c|l|l|l|l|l|}
\hline Country & $\begin{array}{l}\text { Quality } \\
\text { of overall } \\
\text { infra- } \\
\text { structure }\end{array}$ & $\begin{array}{l}\text { Quality of } \\
\text { roads }\end{array}$ & $\begin{array}{l}\text { Quality of } \\
\text { railroad } \\
\text { infra- } \\
\text { structure }\end{array}$ & $\begin{array}{l}\text { Quality of } \\
\text { port infra- } \\
\text { structure }\end{array}$ & $\begin{array}{l}\text { Quality of } \\
\text { air trans- } \\
\text { port infra- } \\
\text { structure }\end{array}$ & $\begin{array}{l}\text { Quality of } \\
\text { electricity } \\
\text { supply }\end{array}$ \\
\hline Singapore & 5 & 7 & 10 & 2 & 1 & 8 \\
\hline Malaysia & 25 & 23 & 18 & 24 & 20 & 37 \\
\hline Brunei & 39 & 35 & $\mathrm{n} / \mathrm{a}$ & 49 & 55 & 59 \\
\hline Thailand & 61 & 42 & 72 & 56 & 34 & 58 \\
\hline Indonesia & 82 & 78 & 44 & 89 & 68 & 89 \\
\hline Philippines & 98 & 87 & 89 & 116 & 113 & 93 \\
\hline Vietnam & 110 & 102 & 58 & 98 & 92 & 95 \\
\hline Laos & 65 & 65 & $\mathrm{n} / \mathrm{a}$ & 137 & 76 & 61 \\
\hline Cambodia & 86 & 80 & 91 & 81 & 90 & 112 \\
\hline Myanmar & 146 & 138 & 104 & 136 & 146 & 118 \\
\hline
\end{tabular}

Source: World Economic Forum (2013).

that poor infrastructure is having on industrial operations. According to Asian Development Bank (ADB) estimates, the Asian countries will need to invest US\$8 trillion in national infrastructure and another US $\$ 290$ billion in interregional infrastructure construction between 2010 and 2020 to realize Asian growth prospects. ${ }^{11}$ It is anticipated that the ten ASEAN countries will require a large share of this estimated infrastructure investment. According to Goldman Sachs' estimate (2013), ${ }^{12}$ Thailand, Malaysia, Philippines and Indonesia (the ASEAN-4) will need up to US $\$ 550$ billion in investment between 2013 and 2020; the railroad sector alone will need US\$119 billion in investment, accounting for 22 per cent of the total projected investment needs.

Building high-speed railways will help ASEAN members reduce interregional transport cost and journey time for passenger traffic and facilitate the free communication of people. It will enhance regional connectivity while also forging economic integration within the ASEAN region. However, many ASEAN countries lack sufficient financial resources to fund large-scale infrastructure projects. In addition, as they are characterized by long implementation periods, high financial and political risks as well as uncertain economic returns, mega-scale infrastructure projects tend to have difficulty attracting private investment. ASEAN members so far have been able to secure a few million dollars in funding for the interregional infrastructure projects outlined in the Master Plan on ASEAN Connectivity (the Master Plan).${ }^{13}$ It needs to look 
for other reliable external sources of funding. The ASEAN is fully aware that it needs foreign investment for its infrastructure modernization. As stated in the Master Plan:

ASEAN will further strengthen partnership with external partners, including Dialogue Partners, multilateral development banks, international organizations and others for effective and efficient implementation of the Master Plan. (pp. ii-iii) ${ }^{14}$

Against this backdrop, the ADB invested US\$7.32 billion in the ASEAN countries for projects on poverty reduction and infrastructure development in 2012. Vietnam, Indonesia and Thailand are the three largest recipients of $\mathrm{ADB}$ loans in the region, receiving 14.4, 6.0 and 6.3 per cent of the ADB's total lending respectively. However, the ADB invested relatively little in Laos, Cambodia, Malaysia and Myanmar (Table 2).

\section{China's High-speed Rail Development Proposals for the ASEAN}

\section{The Rationale behind China's Proposals for the Region}

In recent years, the Chinese government has encouraged Chinese companies to invest overseas, expand their foreign markets and develop strategic resources to sustain domestic economic growth. The ASEAN countries have become an important recipient of the investment from China. According to data issued by the Heritage Foundation of the United States, Chinese companies spent US $\$ 386.7$ billion in outward investment between 2005 and 2012, a trend that is likely to continue over the next decade. During this period, Chinese companies made huge investments in outward transport and other infrastructure construction amounting to about US $\$ 138.8$ billion, exceeded only by investment in the energy and power sector. ${ }^{15}$

China's high-speed rail diplomacy to the ASEAN is pragmatic, being politically as well as economically motivated. First, diplomatically, the Chinese government has reiterated that China aims to promote cooperation and common development with neighbouring countries, rather than seeking regional hegemony. ${ }^{16}$ China's ability to export its high-speed rail expertise to the ASEAN and its acceptance by ASEAN members will be a major test of China's capacity to further strengthen its economic and strategic cooperation with member states and testify to China's long-held 'friendly and good neighbourhood' policy in the context of the rise of China. During the visit of China's president, $\mathrm{Xi}$ Jinping to Indonesia in 
TABLE 2: Loan Approvals to Southeast Asian Nations by the Asian Development Bank, 2012

\begin{tabular}{|l|c|c|}
\hline Country & $\begin{array}{l}\text { Total value of approval } \\
\text { lending (US\$ billion) }\end{array}$ & $\begin{array}{c}\text { As a percentage of total } \\
\text { lending by the ADB }\end{array}$ \\
\hline Cambodia & 350.8 & 1.6 \\
\hline Indonesia & 1.287 .6 & 6.0 \\
\hline Laos & 144.5 & 0.7 \\
\hline Malaysia & 0.3 & 0 \\
\hline Myanmar & 5.4 & 0 \\
\hline Philippines & $1,063.2$ & 6.9 \\
\hline Thailand & $1,360.4$ & 6.3 \\
\hline Vietnam & $3,112.0$ & 14.4 \\
\hline ADB Total & $21,571.3$ & 100 \\
\hline
\end{tabular}

Note: Total value of loan approval by the bank covers its Ordinary Capital Resources (OCR), ADB Special Funds and Co-financing.

Source: Statement of the Asian Development Bank's Operations in 2012, p. 7.

October 2013, he noted to the Indonesian Parliament that 'China would like to expand cooperation with the ASEAN countries in all aspects, to share development opportunities with the ASEAN countries and stand shoulder to shoulder to meet challenges, and pursue common development and prosperity. ${ }^{17}$ From the external perspective, China is using its advanced high-speed rail expertise as a diplomatic tool to serve its foreign policy and enhance its own national interests and regional influence. Second, from a political perspective, by promoting bilateral high-speed rail and other forms of infrastructure cooperation, China seeks to soften its hard-line tone on territorial disputes with other member states of the ASEAN, and strengthen mutual trust between the various parties. Third, the high-speed railroad provides China with new opportunities to engage with the ASEAN member states and pursue its national economic interests abroad. China's initiative to build high-speed railroads will help forge closer economic cooperation between China and the ASEAN. China is keen to aid ASEAN countries in modernizing their infrastructure and hence supports the participation of Chinese companies in ASEAN infrastructure development projects. ${ }^{18}$

The huge and unexplored infrastructure market in general and the high-speed railway market in particular in the ASEAN offer not only enormous business opportunities for China's infrastructure construction companies, but they will also boost the export of high-speed railway technology, high-end railway-related equipment and components by Chinese manufacturing firms to the ASEAN, supported by concessional 
loans and development assistance. Such exports to the Southeast Asian countries will help China deal with its production overcapacity in the rail sector and boost its manufacturing industries and domestic economy.

As the domestic economy slows, the fast expansion of high-speed railway in China is also likely to slow down. China already has the world's largest high-speed rail network, with nearly 10,000 kilometres of track in operation by 2012. There is limited scope for further highspeed rail development in China. Given the seriousness of the manufacturing overcapacity issue, China has to look for foreign markets for its high-speed rail products and associated technology to support its wide-ranging industrial sectors. Against this backdrop, the Chinese government in the past several years has adopted a 'going-out' strategy to promote China's high-end and high-value-added manufacturing industries overseas and strengthen the global competitiveness of China's industrial products.

The main purpose of China's high-speed rail diplomacy is to safeguard its national economic interests in terms of supporting China's outward investments, restructuring industrial development by supporting industrial upgrading towards high-value-added products, as well as boosting domestic manufacturing-led economic growth. China's high-speed rail industry has vital linkages to the various upstream and downstream sectors, including steel, cement and high-end equipment manufacturing industries.

\section{Rivalry between China and Japan over the ASEAN High- speed Rail Sector}

Relations between China and Japan, which were already notoriously difficult due to the historical issue of Japan's wartime atrocities and invasion of China (Beeson and Li 2012), have soured further in recent years mainly due to the ongoing territorial disputes over the Diaoyu/ Senkaku Islands in the East China Sea. China and Japan have engaged in fierce international competition in political, economic, security and defence arenas since the nationalization of the Diaoyu/Senkaku Islands by the Japanese government in 2010. China and Japan both claim these disputed islands as their sovereign territory.

These two countries are also engaged in rivalry over regional leadership in Southeast Asia. The ASEAN, comprising Japan and China's neighbouring countries, has become the major battlefield on which each of these two main Asian powers is desperately trying to solicit support 
against the other. The ASEAN as the major site for contestation provides a glimpse of the fierce competition between Japan and China. China's competition with Japan over high-speed rail exemplifies this battle. Through its high-speed rail diplomacy with ASEAN members, China seeks to wrest regional influence from Japan and to shape the Asian power structure. Meanwhile, with its increasing economic dependence on China, the ASEAN does not want to become embroiled in any conflict between Japan and China.

Japan once was a dominant player in the region. As it is the largest donor of official development assistance to the ASEAN, Japan has established strong bilateral relationships with the ASEAN states. For years, Japanese companies invested more heavily than China in the ASEAN in a wide range of fields including infrastructure development, manufacturing industries, human resource development, education and poverty reduction. Nevertheless, China's investment in Laos, Cambodia and Myanmar has exceeded that of Japan, with much of this investment devoted to transport and other infrastructure construction in these Mekong countries. Hence, from an economic perspective, they have formed strong bonds with China (Chug 2011).

Despite being a relative latecomer to the region, China has successfully caught up with Japan in terms of economic cooperation and integration with the ASEAN. Significantly, China was the first country to propose and sign a free trade agreement (FTA) with the ASEAN. China has overtaken Japan to become the largest trade partner for the ASEAN since 2009. In addition, the rise of China to replace Japan as the world's second largest economy in 2010 has caused much upset, fear and anxiety among many Japanese, who consider China as posing the most serious threat to Japan. China, meanwhile, has flexed its new economic power vis-à-vis Japan by providing significant amounts of economic assistance to the ASEAN nations and financing many large-scale intraregional and interregional infrastructure projects.

China has asserted its increasing economic power through high-speed rail and its other economic interests in Southeast Asia. However, Japan is a long-standing global leader in the field of high-speed rail expertise, due to its Shinkansen (bullet train), and it is thus hard for Japan to accept China's newfound international supremacy in the field of highspeed rail. The expanding influence of China's high-speed rail poses a challenge to Japan's economic and political influence in the ASEAN, demonstrating the continuing rivalry between the two nations over regional influence in the ASEAN. Japan opposes China's high-speed 
rail development proposal for the ASEAN, and is determined to resist Chinese expansion of high-speed rail in the region.

Japan has played a very active role in infrastructure development in the ASEAN over the last several decades; for example, it has long been an important partner with Thailand in projects such as the Bangkok metro system, and is seeking to export its bullet train to Thailand. Moreover, during his visit to Malaysia in July 2013, the Japanese prime minister Shinzo Abe expressed Japan's concern to safeguard the construction contract for the KL-Singapore high-speed railroad project. ${ }^{19}$ For ASEAN, the use of Japanese technology to build their high-speed railroads has great appeal as it is perceived to be superior to Chinese technology. In addition, the trump card for Japan's ASEAN high-speed diplomacy is that Japan is not perceived to be a security threat to the region, as it has not entered into territorial disputes with any member state.

Meanwhile, Japan has serious concerns over China's increasing influence and active role in the ASEAN, and the Japanese government is determined to match China's effort to consolidate its interests in the region. Prime Minister Abe has demonstrated his resolve to use foreign policies to strengthen Japan's long-held economic and political ties with the ASEAN member states, and rally ASEAN bloc solidarity to counterbalance the rise of China's influence in the region.

Japan's interests in the ASEAN relate not only to high-speed rail and other commercial sectors, but also broad political, security and strategic dimensions. Japan seeks to turn the ASEAN into an economic and diplomatic hedge opposing China (Zhao 2013). Since Abe came to power in December 2012, he has visited all of the ten ASEAN member states within one year in a clear attempt to strengthen bilateral relations at China's expense. He visited Indonesia, Thailand and Vietnam in January 2013 and travelled to Myanmar in May of the same year. In July, he visited Malaysia, Singapore and the Philippines. He returned to the region to visit Brunei, Cambodia and Laos in October. Abe's frequent visits to the ASEAN countries are viewed as network diplomacy and as an important part of Japan's China-encirclement policy (Inoguchi 2014).

China and Japan, as the two major Asian powers, are in direct competition in soliciting support from the ASEAN bloc by offering financial aid and loans. The Japan-ASEAN summit conducted in Tokyo in December 2013 to mark the 40th anniversary of Japan-ASEAN relations, was notable for the efforts by Japan to match and directly oppose China's infrastructure plan for the ASEAN. During this summit, Prime Minister Abe pledged a package amounting to US $\$ 20$ billion to the ASEAN over 
the next five years, much of which would be in the form of concessional loans. ${ }^{20}$ Much of this financial package will be channelled into infrastructure construction in the region. In addition, Japan gave US\$53 million and sent 1,000 troops to the Philippines for infrastructure reconstruction and disaster relief after the devastation there caused by Typhoon Haiyan. ${ }^{21}$ Moreover, Japan has offered US\$610 million to Myanmar for infrastructure development.

Such a strategy by Japan, on the one hand, seeks to forge a united front with the ASEAN against China in exchange for Japan's financial assistance. Member states of the ASEAN such as Vietnam, Philippines and Malaysia are the primary targets for Japan, and each of these nations has maritime disputes with China in the SCS. On the other hand, the Abe administration anticipates that aiding ASEAN infrastructure development and the promotion of high-speed rail technology in this region will help to stimulate Japan's exports and economic growth and this represents part of Abe's strategy to revive the stagnating Japanese economy.

However, despite the diplomatic and economic efforts made by the Japanese government and Abe himself, Japan has not sold its Shinkansen trains to any other country to date. With reference to the ASEAN countries discussed, countries such as Malaysia and Thailand have merely acknowledged Japan's capability regarding advanced high-speed railway technology and encouraged Japanese companies to participate in bidding for high-speed railway construction projects in their countries.

Overcoming this strong disposition towards Japanese technology and Japan's efforts to oppose China's proposal to the ASEAN will be a challenging task for China. Nevertheless, China has three trump cards to play in attempting to overcome Japan's opposition. First, China is a rising global economic power with huge capital reserves and other financial resources. During high-profile trips to five ASEAN countries in October 2013, President Xi Jinping and Premier Li Keqiang of China, announced China's plan to establish the Asian Infrastructure Investment Bank (AIIB) to finance Asian infrastructure development and support Chinese firms in expanding into high-speed rail and other infrastructure markets in the ASEAN. ASEAN connectivity-related infrastructure projects will be the bank's priority. China's capability to offer loans to the ASEAN and establish the AIIB is a reflection of its growing economic power. Furthermore, the AIIB seeks primarily to compete rather than collaborate with the Japanese-controlled ADB in future. 
The ADB, founded in 1966 and based in the Philippines, has traditionally been the major player in funding poverty reduction and infrastructure construction projects in Asian countries at concessional rates and terms. Japan and the United States are the two largest shareholders in the ADB, with each accounting for 15.6 per cent of ADB shareholdings in 2012. On the other hand, China is only the third largest shareholder in the bank, with 6.4 per cent of shareholdings, which is less than half of those of Japan and the United States (Table 3)

The current president and chairperson of the board of directors of the ADB is Takehiko Nakao, who is Japanese. China is unhappy with TABLE 3: Asian Development Bank Shareholdings (31 December 2012)

\begin{tabular}{|l|c|}
\hline Member states & Shareholdings (\%) \\
\hline Japan & 15.6 \\
\hline United States & 15.6 \\
\hline China & 6.4 \\
\hline India & 6.3 \\
\hline Australia & 5.8 \\
\hline Indonesia & 5.4 \\
\hline Canada & 5.2 \\
\hline South Korea & 5.0 \\
\hline Germany & 4.3 \\
\hline Malaysia & 2.7 \\
\hline Philippines & 2.4 \\
\hline France & 2.3 \\
\hline Pakistan & 2.2 \\
\hline United Kingdom & 2.0 \\
\hline Italy & 1.8 \\
\hline New Zealand & 1.5 \\
\hline Thailand & 1.4 \\
\hline Taiwan & 1.1 \\
\hline Others & 13.0 \\
\hline
\end{tabular}

Source: ADB Financial Profile (2013: 8).

Japan's control over the loan operations, investment priorities and other operational aspects of the bank. In 2009, for instance, the ADB approved a loan to a controversial water management project located in the border area between China and India. It triggered strong protest from China. The Chinese government is seeking to establish a similar development bank that would focus on Asian infrastructure development. This bank could be controlled by China, with other Asian countries able to participate. 
The Chinese government aims to forge a close strategic partnership with the ASEAN, based not on rhetoric but on tangible infrastructure and trade cooperation. China has proposed to upgrade the China-ASEAN Free Trade Area and aims to achieve bilateral trade worth up to US\$1 trillion by 2020; this will help increase the already burgeoning economic integration between China and the ASEAN. ${ }^{22}$ China's initiative for setting up the AIIB has been widely welcomed by the ASEAN states, including key members such as Indonesia, Thailand and Malaysia. The ASEAN knows that it needs China's financial aid to hasten its infrastructure development and China is replacing Japan as the most important source of investment and loans for infrastructure development in the ASEAN. In fact, China has given more aid and loans to the ASEAN than other regional and international banking organizations such as the ADB and World Bank since the outbreak of the economic crisis in 2008. The ongoing global economic downturn further endorses China's importance in boosting infrastructure development and economic growth in the ASEAN.

However, funding infrastructure development is a complicated task, and it could bring serious political and economic risks. Transforming the proposed AIIB into a professional investment bank will require considerable expertise and credibility, both of which will take time to develop. The Japanese-controlled ADB has had a presence in the ASEAN for decades by offering billions of dollars of loans and aid to the underdeveloped ASEAN members for transportation, other infrastructure and anti-poverty development projects. Taking this into account, it will take years for the AIIB to be able to compete with the ADB's expertise and well-established investment network within the ASEAN.

Second, the superiority of China's high-speed rail technology lies in its speed and its green credentials in terms of low carbon emissions and energy conservation (Yu and Yang 2011). China has achieved rapid development in high-speed railway technology at competitive prices. For example, compared to the construction cost of around US\$50 million per kilometre for Japan's bullet train, China can provide high-speed rail for up to one-third less in price per kilometre, at about US\$33 million.

Third, compared to Japan, China is willing to be flexible regarding loan repayments for high-speed rail from the receiving countries. Thailand, for instance, in the face of public financial constraints, is seeking to make a partial payment to China to build its high-speed railway in the barter form of agricultural products (e.g. rice). ${ }^{23}$ China has agreed to this so-called 'rice for high-speed rail' deal and will import 1 million 
tonnes of Thai rice and more rubber from Thailand over the next five years. Compared to the rice produced in countries such as Vietnam and India, the price of Thai rice is internationally uncompetitive due to the controversial scheme introduced by the Thai government in October 2011 to support local farmers by buying their rice at well above market prices. Thailand has therefore found it difficult to sell its rice in the international market, resulting in record stockpiles of rice amounting to 16 million tonnes. ${ }^{24}$ However, the details of this proposed high-speed rail deal between the Chinese and Thai governments remain unknown. The two governments have to work together on the payment details and make this barter deal workable.

\section{Challenge to China's ASEAN High-speed Rail Development Proposals}

The major challenge to China's ambitious proposals for high-speed rail and other infrastructure investment in the ASEAN is political rather than economic. China's economic power is rising and cooperation with the ASEAN on infrastructure and trade is increasing, while mutual political trust between the ASEAN and China is quite low. Many ASEAN member states have raised serious concerns that China's political ambitions and regional hegemony are undermining their freedom of action and political autonomy. ${ }^{25}$ The ASEAN has expressed concern over the lack of transparency of the Chinese leaders' decision-making process, while the perceived opacity of China's political system has impeded China's efforts to gain trust within this region (Yahuda 2013). Indeed, the ASEAN has warned that China's involvement in large-scale infrastructure development could potentially have a negative impact on regional security.

One concern for the ASEAN is that China-funded, large-scale infrastructure projects have often come with a large number of Chinese engineers and manufacturing workers. As shown in cases in Africa, these infrastructure projects have rarely employed local workers, and the Chinese infrastructure companies have shown little interest in training local workers or transferring advanced technologies to local partners. It should be noted that much of the equipment used by Chinese companies for infrastructure construction projects abroad is sourced domestically in China. Thus, local communities and industries within the ASEAN might not reap much economic benefit from the construction of high-speed railroads and other large-scale infrastructure projects funded by China. 
The most serious challenge facing China is the ongoing territorial disputes and maritime conflicts in the SCS. Based on its self-proclaimed, so-called 'nine dotted line', China asserts that most of the islands in the SCS, along with their surrounding waters and resources, have been an inalienable part of its territorial sovereignty since ancient times. However, the Paracel/Xisha and Spratly/Nansha Islands and their surrounding waters in the SCS are all claimed by China, Vietnam, the Philippines, Brunei and Malaysia individually, while China has conducted several naval exercises in the SCS since 2010. China's assertiveness in claims of territorial sovereignty and maritime disputes in the area since 2009 has set off alarm bells for many ASEAN countries, such as the Philippines and Vietnam. China's relations with the Philippines have deteriorated over recent years. In May 2014, the Philippines condemned China's action on land reclamation to build new facilities on a SCS reef that is the subject of a dispute between the two countries. ${ }^{26}$ On 11 May 2014, several large-scale rallies and protests took place in Vietnam's major cities, including Hanoi and Ho Chi Minh City, ${ }^{27}$ where people vented their anger over a deep-water oil drilling operation conducted by a state-owned Chinese company in disputed waters of the SCS. ${ }^{28}$

Some scholars argue that the prospects for resolution of the SCS sovereignty conflicts are limited (Yahuda 2013: 455-456). China and the ASEAN member states have yet to start negotiating a legally binding document of maritime code of conduct to manage the conflicts and territorial disputes in the SCS. Although the Philippines and Vietnam prefer to emphasize ASEAN centrality (Scott 2012) and the key role ASEAN has to play in resolving the SCS territorial disputes with China, China insists that the SCS issue cannot be dealt with between China and the ASEAN as a group. The Chinese government has stubbornly insisted on the principle of dealing with SCS territorial disputes with the ASEAN member states on an individual bilateral basis and has rejected multilateral negotiations via the ASEAN. The ongoing territorial disputes and maritime interests between the ASEAN and China in the region surrounding the SCS thus are seen as the major obstacle to the deepening of bilateral relationships (Yeoh 2011), and could have longterm negative repercussions for relations between China and Southeast Asia (see for example, Li 2010).

ASEAN members have consequently become very wary of any move made by China in the region. From the ASEAN perspective, China's growing military power, especially the building of a blue-water navy, is widely perceived as a form of deterrence to endorse its sovereignty claim 
over the SCS. As Ho's study (2001) rightly points out, China's vast size, huge market potential and growing military capabilities have presented both opportunities and threats to the ASEAN. Taking this into account, the ASEAN welcomes the United States' 'pivot to Asia' strategy as a hedge or counterbalance against the rise of China, while China views the actions and maritime claims by the Philippines and Vietnam on the SCS as a challenge to its territorial integrity and 'core interest'.

In addition, despite pledges by the leaders of both China and the ASEAN member states to strengthen bilateral cooperation, ChinaASEAN relations remain quite fragile and are characterized by areas of contention and competition. The 'China threat' is still rooted in the mentality of many local people in this region. Economic and trade relations between China and the ASEAN are regarded as competitive rather than complementary, taking into account similarities in their development stage and in trade and industrial structure (Wong and Chan 2003). According to Wong and Chan (2003: 519), 'As is already occurring, ASEAN economies are facing competitive pressures from China, which is fast becoming a manufacturing threat to many Asian countries, not just in low-tech areas but also in some high-tech sectors.'

This is certainly true for the labour-intensive and low-end manufacturing industries in the Philippines and Indonesia, which are losing out to competition from China. The ASEAN member states have seen their export market share in Western industrialized countries decline in the face of cheap manufactured products made in China (Ravenhill 2006). China faces challenges in engaging in high-speed railway and other infrastructure development in the ASEAN market unless it can convince the ASEAN member states that its proposals are purely commercial and can successfully present economic cooperation as a win-win situation. Currently academia and the local media in the ASEAN fear that China's high-speed rail proposals for the region, although not competing directly with low-end local industries in the ASEAN, might endanger and even destroy local manufacturing businesses in this region.

\section{Conclusion}

Accompanying China's astounding emergence as the world's leading player in high-speed rail development projects, the Chinese government has adopted a 'going-out' strategy and actively promoted China's high-speed rail technology in foreign markets. China is eager to get involved in the construction of high-speed railroads in the ASEAN as 
an endorsement of its status as a credible international player in the high-speed rail industry.

China and Japan, meanwhile, are engaging in a fierce contest in Southeast Asia. China faces a challenging task in seeing off competition with Japan over ASEAN infrastructure development, with the latter making every effort to match China's plans. In the face of Japanese rivalry over the high-speed rail sector in the region, China has various advantages over Japan. China can construct and operate high-speed rail at much lower cost than the Japanese. In addition, China's announcement of its plan to establish the AIIB to finance ASEAN connectivity-related infrastructure projects and offer further financial aid to the ASEAN countries has been welcomed by the ASEAN and has increased China's chances of participating in the ASEAN high-speed rail market. This trend of high-tech Chinese exports to other nations is likely to continue in the coming decade.

Nevertheless, China is facing serious challenges to implementing its plan for the ASEAN. Although there is close bilateral trade cooperation, political trust between China and the ASEAN is relatively low due to ongoing maritime disputes in the SCS and China's growing military power. China has to convince the ASEAN member states that infrastructure cooperation between China and the ASEAN is a win-win situation.

Thailand is an influential country within the ASEAN region and plays an important role in the development of China-ASEAN rail infrastructure cooperation. The above-mentioned SKRL is a flagship project for the ASEAN's connectivity goal, and, whichever of the proposed eastern or western routes is chosen, it has to go through Thailand. Thailand is located at a strategic crossing point for the interregional rail link within the ASEAN. This is a further incentive for China to achieve a breakthrough in Thailand by engaging in the building of high-speed railroads in this region. If China successfully bids for the construction of the Bangkok-Chiang Mai rail line, it will be a symbolic landmark, both for China in accessing the ASEAN infrastructure market and for overseas expansion by China's infrastructure companies.

Dr. Hong Yu is Research Fellow at the East Asian Institute, National University of Singapore. Email: eaiyuh@nus.edu.sg 


\section{NOTES}

1 For the details, please refer to 1) 'High-speed rail, regional economics, and urban development in China', China Transport Topics No. 8, January 2013, World Bank; 2) 'High-speed railways: faster than a speeding bullet', The Economist, 9 November 2013, available at http:/ / www.economist.com/news/china/21589447-chinas-newrail-network-already-worlds-longest-will-soon-stretch-considerably-farther-faster (accessed 24 December 2013); 3) 'China unveils high-speed railways', BBC News, http://news.bbc.co.uk/2/hi/asia-pacific/8246600.stm (accessed 24 December 2013); 4) 'High-speed rail poised to alter China', The New York Times, 22 June 2011, http:/ / www.nytimes.com/2011/06/23/business/global/23rail.html?pagewanted=all\&_ $\mathrm{r}=0$ (accessed 24 December 2014).

2 'UK nuclear power plant gets go-ahead', BBC News, 21 October 2013, available at http:/ / www.bbc.co.uk/news/business-24604218 (accessed 24 December 2013).

3 'Zhongguo tongyi taiguo dami huan gaotie" (China agreed the barter deal with Thailand on the construction of high-speed railway), Dongfang Daily, 13 October 2013, available online at http:/ / www.dfdaily.com/html/51/2013/10/13/1078379.shtml (accessed 7 November 2013).

4 'High-speed rail, regional economics, and urban development in China', China Transport Topics No. 8, January 2013, World Bank.

5 'Connecting Kuala Lumpur \& Singapore through high speed rail link, 14 March 2013, Land Public Transport Commission, Government of Malaysia.

6 'Premier Li Keqiang holds talks with Prime Minister Yingluck Shinawatra of Thailand, stressing to leverage exemplary and leading role of China-Thailand relations', Ministry of Foreign Affairs of the People's Republic of China, available online at http:/ / www.fmprc.gov.cn/eng/topics/lkqzlcxdyldrxlhy/t1089420.shtml (accessed 6 November 2013).

7 'Thailand plans to spend \$60bn on new railway lines', BBC News, 30 August 2013, available online at http://www.bbc.co.uk/news/business-23894162 (accessed 5 December 2013).

8 'China shares up on Thai fast-rail', Bangkok Post, 14 October 2013, available online at http://www.bangkokpost.com/news/transport/374615/china-rail-shares-riseon-thai-high-speed-rail (accessed 7 November 2013).

9 In addition to physical connectivity, the other two pillars to connect ASEAN are institutional and people-to-people connectivity.

10 'ASEAN's half a trillion dollar infrastructure opportunity'. Asia Economics Analyst Issue 13/18, 30 May 2013, Goldman Sachs.

11 'For a better road to development, Asia must attract private partners', Asian Development Bank, 3 May 2012, available online at http:/ / www.adb.org/news/op-ed/betterroad-development-asia-must-attract-private-partners (accessed 2 December 2013).

12 'ASEAN's half a trillion dollar infrastructure opportunity'. Asia Economics Analyst Issue 13/18, 30 May 2013, Goldman Sachs.

13 Prashanth Parameswaran, 'Beijing unveils new strategy for ASEAN-China relations', China Brief XIII (21), 24 October 2013, the Jamestown Foundation, Washington D.C.

14 'Master Plan on ASEAN Connectivity', ASEAN Secretariat, Jakarta, Indonesia, January 2011.

15 Derek Scissors, 'China's global investment rises: the U.S. should focus on competition', The Heritage Foundation, 9 January 2013, available online at http://www.heritage. org/research/reports/2013/01/chinas-global-investment-rises-the-us-should-focus-on-competition (accessed on 5 December 2013).

16 Zheng, Bijian, 2013, 'China's peaceful rise and opportunities for the Asia-Pacific region', 
speech at the Boao Forum for Asia, 13 December 2013, http:/ /english.boaoforum. org/document2004/11162.jhtml (accessed 11 August 2014).

17 'Xi Jinping gives a speech in the Indonesian parliament', Xinhua News, 3 October 2013, http://www.xinhuanet.com/world/xjpynghyj/index.htm (accessed 27 February 2014).

18 'China, Indonesia aim for $\$ 80 \mathrm{~b}$ in trade by 2015 ', China Daily, available online at http://www.chinadaily.com.cn/china/2013xiapec/2013-10/03/content_17008814. htm (accessed 3 December 2013).

19 'Singapore-KL rail link could feature Japan technology', Today, available online at http://www.todayonline.com/world/asia/spore-kl-rail-link-could-feature-japantechnology (accessed 7 November 2013).

20 'Japan, ASEAN pledge to work more closely together', The Wall Street Journal, 15 December 2013, available at http://online.wsj.com/news/articles/SB1000142405 2702304173704579259931798199724 (accessed 24 December 2013).

21 'Japan looks for ASEAN backing on China at summit', AFP News, 12 December 2013, available at http:/ / sg.news.yahoo.com/japan-looks-asean-backing-china-summit045449866.html (accessed 17 December 2013).

22 'President Xi gives speech to Indonesia's parliament', China Daily, 2 October 2013, available online at http:/ / www.chinadaily.com.cn/china/2013xiapec/2013-10/02/ content_17007915_3.htm (accessed 4 December 2013).

23 'China extends charm offensive to Thailand', The Wall Street Journal, 12 October 2013, http:/ / blogs.wsj.com/chinarealtime/2013/10/12/china-extends-charm-offensiveto-thailand/ (accessed 6 November 2013).

24 'China pledges to buy 1 million tonnes of Thai rice a year: Thai PM', Today, 13 October 2013, available online at http:/ / www.todayonline.com/world/asia/china-pledgesbuy-1-million-tonnes-thai-rice-year-thai-pm\#inside (accessed 7 December 2013).

25 'Can't buy me soft power', The Economist, 27 April 2013, available online at www. economist.com/news/china/21576661-chinas-economic-might-not-doing-much-itspopularity-elsewhere-asia-cant-buy-me-soft-power (accessed 2 December 2013).

26 'Philippines says China appears to be building airstrip on disputed reef', Reuters, 13 May 2014, available at http:/ / www.reuters.com/article/2014/05/14/us-philippines-china-reef-idUSBREA4D00K20140514 (accessed 15 May 2014).

27 The author was in Ho Chi Minh City, Vietnam in May 2014 and witnessed a largescale, anti-China protest near the Opera House, in the centre of Ho Chi Minh City. There were roughly one thousand protestors at the scene. Some of these were draped in Vietnamese flags to encourage the Vietnamese government to stand firm against China.

28 'Beijing pays a price for assertiveness in South China Sea', Wall Street Journal, 13 May 2014, available at http:/ / online.wsj.com/news/articles/SB100014240527023036275 04579558913140862896 (accessed 15 May 2014).

\section{REFERENCES}

Asian Development Bank 2012. 'The impact of ACFTA on People's Republic of China-ASEAN trade'. ADB Working Paper Series on Regional Economic Integration, No. 99 (July).

Beeson, Mark, and Fujian Li 2012. 'Charmed or alarmed? Reading China's regional relations'. Journal of Contemporary China 21 (73): 35-51.

Bougheas, S., P.O. Demetriades, and E.L.W. Morgenroth 1999. 'Infrastructure, transport costs and trade.' Journal of International Economics 47: 169-89. 
Hong Yu

Chung, Chien-Peng 2011. 'Japan's involvement in Asia-centered regional forums in the context of relations with China and the United States'. Asian Survey 51 (3): 407-428.

Das, Dilip K. 2013. 'China and the Asian economies: mutual acceptance, economic interaction and interactive dynamics'. Journal of Contemporary China 22 (84): 1089-1105.

Devadason, Evelyn 2010. 'ASEAN-China trade flows: moving forward with ACFTA'. Journal of Contemporary China 19 (66): 653-674.

Henderson, J.V., Z. Shalizi, and A.J. Venables 2001. 'Geography and development'. Journal of Economic Geography 1: 81-105.

Ho Khai Leong 2001. 'Rituals, risks and rivalries: China and ASEAN in the coming decades'. Journal of Contemporary China 10 (29): 683-694.

Inoguchi, Takashi 2014. 'Japan in 2013: Abenomics and Abegeopolitics'. Asian Survey 54 (1): 101-112.

Kraft, G., J.R. Meyer, and J. Valette 1971. The Role of Transportation in Regional Economic Development. London: D.C. Health and Co.

Li, Mingjiang 2010. 'China and maritime cooperation in East Asia: recent developments and future prospects'. Journal of Contemporary China 19 (64): 291-310.

Radelet, S., and J. Sachs 1998. 'Shipping costs, manufactured exports and economic growth.' Paper presented at the American Economic Association Meetings, Chicago.

Ravenhill, John 2006. 'Is China an economic threat to Southeast Asia?' Asian Survey 46 (5): 653-674.

Reilly, James 2012. 'A norm-taker or a norm-maker? Chinese aid in Southeast Asia'. Journal of Contemporary China 21 (73): 71-91.

Sapir, A. 1990. 'Discussion'. In Unity with Diversity in the European Economy: the Community's Southern Frontier, edited by C. Bliss and J.B. de Macedo, pp. 76-77. Cambridge: Cambridge University Press.

Scott, David 2012. 'Conflict irresolution in the South China Sea'. Asian Survey 52 (6): 1019-1042.

Skinner, G.W. 1994. 'Differential development in Lingnan'. In The Economic Transformation of South China, edited by T.P. Lyons and V. Nee, pp. 17-54. New York: Cornell University Press.

Wong, John, and Sarah Chan 2003. 'China-ASEAN free trade agreement: shaping future economic relations'. Asian Survey 43 (3): 507-526.

World Economic Forum 2013. 'The Global Competitiveness Report 2013-2014'. Geneva: World Economic Forum.

Yahuda, Michael 2013. 'China's new assertiveness in the South China Sea'. Journal of Contemporary China 22 (81): 446-459.

Yeoh, Kok-Kheng Emile 2011. 'Forward China: foreign relations and maritime conflict'. International Journal of China Studies 2 (3): 551-553.

Yu Hong 2011. Economic Development and Inequality in China: The case of Guangdong. London and New York: Routledge.

Yu Hong, and Mu Yang 2011. 'China enters the age of high-speed rail'. In China's Industrial Development in the $21^{\text {st }}$ Century, edited by Yang Mu and Yu Hong, pp. 199-224. Singapore: World Scientific.

Zhao, Hong 2013. 'Japan and China vying for ASEAN support'. EAI Background Brief No. 866, National University of Singapore, 7 November. 